\title{
BUSY BOARDS, FIRM PERFORMANCE AND OPERATING RISK
}

\author{
Kin-Wai Lee ${ }^{1}$ and Char-Lee Lok ${ }^{2 *}$ \\ ${ }^{1}$ S3-B2A9, Division of Accounting, Nanyang Business School, \\ Nanyang Technological University, 50 Nanyang Ave, 639798 Singapore \\ ${ }^{2}$ School of Management, Universiti Sains Malaysia, 11800 USM Pulau Pinang, Malaysia \\ *Corresponding author: lokcl@usm.my
}

\begin{abstract}
Using a sample of listed firms in Malaysia, Philippines, Singapore and Thailand, this paper examines the association between busy board of directors and firm performance. We offer three results. First, we find that firm performance (measured by operating profitability and market-to-book equity) is negatively associated with busy boards. Second, we find that firms with busy boards have higher operating risk (measured by volatility of return on assets, volatility of stock returns and volatility of operating cash flow). Third, we find that the association between firm performance and busy boards is conditional on the firm's life cycle stage. For firms in the growth stage, busy boards are beneficial to firm performance suggesting that the experience knowledge and reputation accumulated with multiple directorships help busy directors to more effectively advise these firms. In contrast, for firms in the maturity stage of their life cycle, busy boards are detrimental to firm performance suggesting the monitoring role of board is weakened by multiple directorships.
\end{abstract}

Keywords: Board business, firm performance, operating risk, firm's life cycle, reputation hypothesis

\section{INTRODUCTION}

The issue of multiple directorships on corporate boards has come under increasing scrutiny from investors and regulators. Several practitioner organisations have adopted resolutions limiting the number of directorships held by directors. For example, in 2015, the Institutional Shareholder Services (ISS) adopted a policy

Publication date: 23 December 2020

To cite this article: Lee, K.-W., \& Lok, C.-L. (2020). Busy boards, firm performance and operating risk. Asian Academy of Management Journal of Accounting and Finance, 16(2), 1-23. https://doi. org/10.21315/aamjaf2020.16.2.1

To link to this article: https://doi.org/10.21315/aamjaf2020.16.2.1

(C) Asian Academy of Management and Penerbit Universiti Sains Malaysia, 2020. This work is licensed under the terms of the Creative Commons Attribution (CC BY) (http://creativecommons. org/licenses/by/4.0/). 
that views directors as "over-boarded" if they serve on five or more public company boards.

In general, there are two competing hypotheses on the effect of multiple directorships on firm value and performance. Under the first hypothesis, which we refer to as the reputation hypothesis, individual directors obtain valuable experience from their multiple board appointments and build professional networks that make them desirable board members. To protect their reputational capital, these directors perform an effective monitoring of management (Gilson, 1990; Kaplan \& Reishus, 1990; Booth \& Deli, 1996; Brickley, Linck, \& Coles, 1999). Under the competing arguments, which we refer to as the busyness hypothesis, individuals who sit on multiple boards become over-committed in time and thus, cannot effectively perform their monitoring of management (Ferris, Jagannathan, \& Pritchard, 2003).

Prior studies provide mixed evidence on whether the reputation or busyness effect is dominant. On one hand, several past studies provide evidence supporting the reputation hypothesis. Perry and Peyer (2005) find that multiple directorships increase firm value in firms with low agency costs. Ferris et al. (2003) find no relation between multiple-board directors and firm performance. For a sample of listed U.S. banks, Elyasiani and Zhang (2015) report that firm performance is positively associated with busyness of directors. Masulis and Mobbs (2011) find that firms with inside directors holding outside directorships have better operating performance and market-to-book ratios especially when monitoring is more difficult. These firms make better acquisition decisions have greater cash holdings and have lower earnings management. ${ }^{1}$ Outside the U.S., single country studies report that busy directors are associated with a higher firm performance in Italy (Di Pietra et al., 2008), Colombia (Pombo \& Gutiérrez, 2011) and India (Sarkar \& Sarkar, 2009).

On one hand, other prior studies providing evidence supporting the busyness hypothesis. Fich and Shivdasani (2006) find that firms with higher proportion of busy directors have lower market-to-book ratios, weaker profitability and lower sensitivity of chief executive officer (CEO) turnover to firm performance. Field, Lowry and Mkrtchyan (2013) suggest that both effects might be present, with young firms enjoying the benefits of reputation and large, established firms suffering the costs of director busyness and over-commitment. Using a sample of international firms, Ferris, Jayaraman and Liao (2020) find that firms with busy boards exhibit lower market-to-book ratios and reduced profitability, but this effect is reversed for younger firms. Using mergers that terminate entire boards, Hauser (2018) shows that a reduction in the number 
of board appointments held by a director is associated with greater profitability and higher market-to-book ratios. Sarkar and Sarkar (2009) report that multiple directorships by inside directors are negatively related to firm performance in India. Using a sample of international firms from 1999 to 2012, Ferris et al. (2020) find that firms with busy boards exhibit lower market-to-book ratios and lower profitability. However, this effect however is reversed for younger firms suggesting that the advising ability of these networked directors is most useful for younger firms. ${ }^{2}$ Using a sample of international firms, Ferris and Liao (2019) find that firms with a higher proportion of busy independent directors have higher earnings management. They also report that firms with a higher proportion of busy independent audit committee members have poorer financial reporting quality.

Using a sample of listed firms in South East Asia (comprising Malaysia, Philippines, Singapore and Thailand), we examine the association between busy board of directors and firm performance. Our choice of South East Asia countries is motivated by the unique institutional features in these countries. First, the code of corporate governance in these countries does not formally impose a limit of number of external board seats per director. For example, the Malaysia Code on Corporate Governance (2012) recommends that "directors should devote sufficient time to carry out their responsibilities. The board should obtain this commitment from its members at the time of appointment. Directors should notify the chairman before accepting any new directorship. The notification should include an indication of time that will be spent on the new appointment." Similarly, the Singapore Code of Corporate Governance (2018) requires that "the company discloses in its annual report, the listed company directorships and principal commitments of each director, and where a director holds a significant number of such directorships and commitments, it provides the Nominating Committee's and Board's reasoned assessment of the ability of the director to diligently discharge his or her duties." Second, family control is the most dominant form of ownership across East Asia and state ownership has become increasingly important to domestic firms and foreign firms (Carney \& Childs, 2013).

Our main research questions are:

1. What is the association between busy board of directors and firm performance?

2. How do busy boards affect the operating risk of firms?

3. Is the association between firm performance (operating risk) and busy boards conditional on a firm's life cycle stage? 
We offer three results. First, we find that firm performance is negatively associated with busy boards. Firms with higher multiple directorships have lower firm valuation (market-to-book equity) and lower operating profitability than those with lower multiple directorships. Second, we document a positive association between busy boards and the firm's operating risk. Specifically, we find that firms with higher percentage of busy directors have higher volatility of return on assets (ROA), higher volatility of stock returns and higher volatility of operating cash flows. Third, we find that the association between firm performance and busy boards is conditional on the firm's life cycle stage. For firms in the growth stage, busy boards are beneficial to firm performance suggesting that the experience knowledge and reputation accumulated with multiple directorships help busy directors to more effectively advise these firms. In contrast, for firms in the matured stage, busy boards are detrimental to firm performance suggesting the monitoring role of board is weakened by multiple directorships.

This paper contains several contributions. First, we find that firm performance (market-to-book valuation and operating profitability) is negatively associated with busy boards. Thus, in our sample, on average, the busyness hypothesis dominates the reputation hypothesis. Second, we show that the association between firm performance and busy boards is conditional on the firm's life cycle stage. Busy boards are beneficial to firms in their growth stage whilst busy boards are detrimental to firms in their maturity stage. Third, we provide evidence on a channel in which busy directors affect firm performance by demonstrating that firms with higher percentage of busy directors have higher operating risk such as stock return volatility and operating return volatility.

\section{LITERATURE REVIEW AND HYPOTHESES}

\section{Firm Performance and Busy Boards}

Under the reputation hypothesis, directors with multiple board appointments have higher reputational capital that increases their monitoring effectiveness (Fama \& Jensen, 1983). They have more experience in governance than those holding a single directorship and often bring to bear substantial industry expertise. Consistent with this reputation hypothesis, there is substantial evidence that directors who serve on the boards of successful firms are more likely to serve on multiple boards, suggesting a positive association between multiple directorships and perceived director quality (e.g., Gilson, 1990; Kaplan \& Reishus, 1990; Shivdasani, 1993; Booth \& Deli, 1996; Brickley et al., 1999; Masulis \& Mobbs, 2011). Perry and Peyer (2005) find that multiple directorships increase firm value 
in firms with low agency costs. ${ }^{3}$ Using a sample of U.S. bank holding companies, Elyasiani and Zhang (2015) report that firm performance (measured by Tobin's Q, return on equity, and ROA) are positively associated with busyness of directors. Di Pietra et al. (2008) find that busy directors are associated with a higher market value of Italian firms. Using a sample of listed firms in Asia, Lee and Lee (2014) find that higher proportion of busy independent directors improves firm valuation in firms with higher external financing needs and firms with higher advising needs such as those with greater organisational complexities and higher proportion of intangible assets. Pombo and Gutiérrez (2011) report that busy directors are associated with improved firm performance in Colombia. Using a sample of firms in India, Sarkar and Sarkar (2009) find that multiple directorships by independent directors are positively associated with firm value. Independent directors with multiple positions also attend more board meetings and are more likely to be present in a company's annual general meeting.

On the other hand, under the busyness hypothesis, multiple directorships increase the workload for directors. Thus, busy directors are overstretched and they may not have sufficient time and energy to monitor and to advise the firm's management. Ferris et al. (2003) find no relation between multipleboard directors and firm performance. In contrast, Fich and Shivdasani (2006) find that firms with higher proportion of busy directors have lower market-tobook ratios, weaker profitability and lower sensitivity of CEO turnover to firm performance. For a sample of initial public offering (IPO) firms (with relatively few connections and little experience in navigating the public markets), Field et al. (2013) find that busy boards contribute positively to firm value. However, they report that the positive relation between firm performance and board busyness is significantly lower for older and more established firms. Cashman, Gillan and Jun (2012) report that "over-boarded" directors are ineffective and detract from firm value. Hauser (2018) examines the effect of mergers and acquisitions (M\&A) that terminate a target firm's board of directors as a shock to multiple directorships and finds that the reduction in multiple directorships at directorinterlocked firms is associated with higher profitability market-to-book ratios and committee participation at interlocked firms. Brown, Dai and Zur (2019) find that firms experiencing a decrease in multiple directorships due to M\&A exhibit improved operating performance monitoring and strategic advising. However, for firms that lost more board connections, the negative effects of the loss of access to board resources and information cancels out the benefits of the decrease in directors' busyness. ${ }^{4}$ Using a sample of international M\&A, Ferris, Jayaraman and Liao (2019) report that that mergers pursued by firms with busy directors are wealth reducing for shareholders. ${ }^{5}$ They contend that there is an optimal level 
of director busyness where the advantages due to reputation, experience and networking turn into disadvantages because of over-commitment.

If the reputation hypothesis of multiple directorships dominates the busyness hypothesis of multiple directorships, we predict:

H1a: Firm performance is positively associated with busy boards.

If the busyness hypothesis of multiple directorships dominates the reputation hypothesis of multiple directorships, we predict:

H1b: Firm performance is negatively associated with busy boards.

\section{Operating Risk and Busy Boards}

Besides monitoring a firm's performance, the board of directors should monitor its operating risk. The board of directors approves the firm's policies, procedures, and business strategies and the ultimate oversight responsibility for its risktaking decisions. Consistent with the reputational hypothesis, Elyasiani and Zhang (2015) find that directors' (both inside and outside/independent directors) busyness is negatively associated with risk-taking.

In contrast, consistent with the busyness hypothesis, Cooper and Uzun (2012) find that bank risk increases when directors hold multiple directorships as "over-boarded" and "over-stretched" directors are less likely to curtail managerial risk-taking actions. Using a sample of banks in South Asia, Kutubi, Ahmed and Khan (2018) find an inverted u-shaped relationship between directors' busyness and bank performance and a u-shaped relationship between directors' busyness and bank risk-taking. Inside directors' busyness has a significant effect on bank performance and risk-taking whereas independent directors' busyness does not have a significant effect on performance and risk-taking. ${ }^{6}$

Thus, if greater board monitoring by busy directors reduces the firm's operating risk, under the reputation hypothesis of multiple directorships, we predict that:

H2a: Operating risk is negatively associated with busy boards.

Under the busyness hypothesis, due to insufficient time and weaker monitoring, busy directors are less likely to constrain the managerial risk-taking propensity. Hence, we predict: 
$\mathrm{H} 2 \mathrm{~b}$ : Operating risk is positively associated with busy boards.

\section{The Effect of a Firm's Life Cycle on the Association between Busy Boards and Firm Performance}

This section predicts that the association between busy boards and firm performance is conditional on a firm's stage in its life cycle. Gort and Klepper (1982) define five life cycle stages:

1. An introductory stage, where an innovation is first produced.

2. A growth stage, where the number of producers increases dramatically.

3. A maturity stage, where the number of producers reaches a maximum.

4. A shake-out stage, where the number of producers begins to decline.

5. A decline stage, where there is essentially zero net entry.

Dickinson (2011) provides evidence that cash flow patterns provide a parsimonious, but robust, indicator of firm life cycle stage that is free from distributional assumptions inherent when using a univariate or composite measure. Dickinson (2011) demonstrates the predictive superiority of the cash flow pattern life cycle measure over univariate sorts used in prior literature to determine life cycle stage such as age, size, sales growth, capital expenditures, research and development, and dividend payments (e.g., Anthony \& Ramesh, 1992; Black, 1998). ${ }^{7}$

When a firm is in its growth stage, its advising needs are stronger than monitoring needs and busy boards are more beneficial (Field et al., 2013; Ferris et al., 2020). Multiple directorships provide firms with access to directors who have more experience, more resources and better social network connections. Thus, we predict that:

H3a: When a firm is in its growth stage, firm performance is positively associated with busy boards.

However, when a firm is in its matured stage, agency costs typically increase and thus, monitoring needs are stronger than advising needs (Field et al., 2013; Ferris et al., 2020). Thus, we predict that:

H3b: Firm performance is negatively associated with busy boards in older firms. 


\section{SAMPLE AND METHOD}

\section{Sample}

We begin with the Standard and Poor's Global Vantage database to identify listed firms in Malaysia, Philippines, Singapore and Thailand from 2012 to 2016. We exclude the firms in the financial industry due to their unique financial characteristics and regulatory requirements. We obtain financial accounting data and stock price data from DataStream. We delete firms with missing financial statement information and stock price information. In view of the cost of data collection, we randomly select 400 firms to obtain their annual reports from their corporate website. Our final sample consists of 400 firms for 1,730 firm-year observations during the period 2012 to 2016.

\section{Measures of Directors' Busyness}

In this study, we focus on the outside directors in the firm because they are responsible for monitoring the management. Outside directors are directors who are not classified as inside or grey directors where grey directors include former employees or persons who have related party transactions with the firm. We count directorships held in listed firms but we do not consider directorships held in private firms, not-for-profit and charitable organisations, trusts and association. We employ three measures of outside directors' busyness. Our first measure of outside directors' busyness is the average number of external directorships per director (AVGDIR) which is computed as the total number of external directorships held by outside directors divided by the number of outside directors. Our second measure of director's busyness is the number of busy directors divided by number of outside directors (BUSYBOD). As in Ferris et al. (2003) and Fich and Shivdasani (2006), we consider a director as busy if he holds three or more directorships. Our third measure of director's busyness is a dummy variable that equals one if $50 \%$ or more of the outside directors are busy and zero otherwise (D_BUSY) where we classify a director as busy if he holds three or more directorships.

\section{Empirical Model}

$$
\begin{aligned}
\text { Firm Performance }_{i t}= & \beta_{0}+\beta_{1} \text { BUSYBOARD }_{i t}+\beta_{2} \text { BUSYBOARD }_{i t}{ }^{*} \text { CYCLE } \\
& +\beta_{3} \text { BDSIZE }_{i t}+\beta_{4} \text { OUTDIR }_{i t}+\beta_{5} \text { DUAL }_{i t}+ \\
& \beta_{6} \mathrm{CYCLE}_{i t}+\beta_{7} \mathrm{INSTI}_{i t}+\beta_{8} \mathrm{LNASSET}_{i t}+\beta_{9} \mathrm{DEBT}_{i t} \\
& +\beta_{10} \mathrm{SALECHG}_{i t}+\mathrm{INDUSTRY}+\mathrm{YEAR}
\end{aligned}
$$

where, subscript $i$ refers to firm and subscript $t$ refers to year; 
Firm Performance $=$ One of the two measures of firm performance:

i. $\quad$ TOBINQ = Ratio of market value of the ordinary equity divided by the book value of the ordinary equity.

ii. $\mathrm{ROA}=$ Net income divided by total assets.

BUSYBOARD is one of the three measures of multiple directorships:

i. $\quad$ AVGDIR $=$ The total number of external directorships held by outside directors divided by the number of outside directors.

ii. $\quad$ BUSYBOD $=$ Number of busy directors divided by number of outside directors. We consider a director as busy if he holds three or more directorships

iii. D_BUSY $=$ A dummy variable that equals one if $50 \%$ or more of the outside directors are busy and zero otherwise (D_BUSY). We classify a director as busy if he holds three or more directorships.

BDSIZE $=$ Total number of directors on the board;

OUTDIR $=$ The proportion of outside directors on the board. Outside directors are directors who directors who are not classified as inside or grey directors where grey directors include former employees or persons who have related party transactions with the firm;

$\mathrm{DUAL}=\mathrm{A}$ dummy variable that equals one if the CEO is chairman of the board and zero otherwise;

CYCLE $=$ An index that ranges from 1 to 5 according to the five firm life cycle stages (Dickinson 2011): Introduction, growth, mature, shake-out and decline, based on expected cash flow generated separately from operating, investing and financing;

INSTI $=$ Proportion of common equity held by institutional shareholders;

LNASSET $=$ The natural logarithm of book value of total assets;

DEBT $=$ Total liabilities divided by book value of total assets;

SALECHG $=$ The prior year sales growth;

INDUSTRY $=$ Dummy variables to control for industry effects using 2-digit SIC codes; 
YEAR $=$ Dummy variables to control for time trends.

For life cycle measures, we construct CYCLE, which is an index that ranges from 1 to 5 according to the five firm life cycle stages (Dickinson, 2011): introduction, growth, mature, shake-out and decline, based on its operating cash flow, investing cash flow and financing cash flow. Following Dickinson (2011), we determine the firm's life cycle based on its cash flow patterns based on Table 1. The variable CYCLE takes the value of one to five based on the five life cycle stages: (i) introduction, (ii) growth, (iii) maturity, (iv) shake-out, and (v) decline. For example, if company constantly has positive financing cash flow but negative operating cash flow and negative investing cash flow, then we classify the company into the introduction stage.

Table 1

Life cycle classification based on cash flow patterns (Dickinson, 2011)

\begin{tabular}{lcccccccc}
\hline Definition & Introduction & Growth & Maturity & $\begin{array}{c}\text { Shake- } \\
\text { out }\end{array}$ & $\begin{array}{c}\text { Shake- } \\
\text { out }\end{array}$ & Shake-out & Decline & Decline \\
\hline $\begin{array}{l}\text { Operating } \\
\text { cash flow }\end{array}$ & - & + & + & - & + & + & - & - \\
$\begin{array}{l}\text { Investing } \\
\text { cash flow }\end{array}$ & - & - & - & - & + & + & + & + \\
$\begin{array}{l}\text { Financing } \\
\text { cash flow }\end{array}$ & + & & + & - & - & + & - & + \\
\hline
\end{tabular}

Our control variables are as follows. As monitoring by outside directors increases, firm performance also increases (Shivdasani, 1993; Perry \& Peyer, 2005). Thus, we include the proportion of outside directors on the board (OUTDIR) in our tests. Prior studies find that smaller boards are associated with higher firm value due to lower coordination problems (Yermack, 1996). Hence, we include board size at the end of the preceding fiscal year (BDSIZE). We also control for the proportion of common equity held by institutional shareholders (INSTI) because prior studies (Lins, 2003) find that large institutional shareholders are associated with more effective monitoring of managers.

We control for firm size by including the natural logarithm of book assets (LNASSET) and profitability (ROA). To control for growth opportunities (Smith $\&$ Watts, 1992), we include prior year's sales growth (SALECHG). To control for the effect of debt financing in mitigating agency costs we include the ratio of long-term debt to total assets (DEBT). We control for industry effects with industry indicators (INDUSTRY) using 2-digit SIC codes and for time trends with year indicators (YEAR). 


\section{RESULTS}

\section{Descriptive Statistics}

Table 2 shows the descriptive statistics. The AVGDIR is 2.832 and the median directorships per outside director is 3.916. The mean percentage of busy outside directors (BUSYOUT) is 52\%. On average, about $56 \%$ of the sample firms have more than $50 \%$ of D_BUSY classified as busy (i.e., holding three or more directorships).

Table 2

Descriptive statistics

\begin{tabular}{lccccc}
\hline & Mean & 25th percentile & Median & 75th percentile & SD \\
\hline TOBINQ & 1.723 & 0.915 & 1.496 & 2.451 & 0.891 \\
AVGDIR & 2.832 & 1.705 & 3.916 & 4.502 & 2.625 \\
BUSYBOD & 0.521 & 0.293 & 0.568 & 0.711 & 0.372 \\
D_BUSY & 0.563 & 0 & 1 & 1 & 0.415 \\
BDSIZE & 8.720 & 7 & 9 & 10 & 4.94 \\
OUTDIR & 0.582 & 0.433 & 0.674 & 0.729 & 0.211 \\
DUAL & 0.280 & 0 & 0 & 0 & 0.491 \\
CYCLE & 2.894 & 1.134 & 2.205 & 3.852 & 1.317 \\
INSTI & 0.128 & 0.051 & 0.092 & 0.157 & 0.049 \\
LNASSET & 6.938 & 4.182 & 7.139 & 9.013 & 3.785 \\
ROA & 0.041 & 0.023 & 0.037 & 0.079 & 0.056 \\
SALECHG & 0.135 & 0.046 & 0.119 & 0.183 & 0.074 \\
DEBT & 0.416 & 0.154 & 0.371 & 0.620 & 0.251 \\
\hline
\end{tabular}

Notes: This table presents the descriptive statistics. The sample consists of 400 firms for 1,730 firm-year observations in Malaysia, Philippines, Singapore and Thailand during the period 2012 to 2016. TOBINQ is the market value of equity plus book value of total liabilities divided by total assets. AVGDIR is the total number of external directorships held by outside directors divided by the number of outside directors. BUSYBOD is the number of outside directors who are busy divided by number of outside directors. We consider a director as busy if he holds three or more directorships. D_BUSY is a dummy variable that equals one if $50 \%$ or more of the outside directors are busy and zero otherwise (D_BUSY). We classify a director as busy if he holds three or more directorships. BDSIZE is the number of directors on the board. OUTDIR is the proportion of outside directors on the board. Outside directors are directors who directors who are not classified as inside or grey directors, where grey directors include former employees or persons who have related party transactions with the firm. DUAL is a dummy variable that equals one if the CEO is chairman of the board and zero otherwise. CYCLE is an index that ranges from 1 to 5 according to the five firm life cycle stages (Dickinson, 2011): Introduction, growth, mature, shake-out and decline, based on expected cash flow generated separately from operating, investing and financing. INSTI is the proportion of common equity held by institutional shareholders. LNASSET is the natural logarithm of book value of total assets. ROA is net income divided by total assets. SALECHG is the prior year sales growth. DEBT is the long-term debt divided by book value of total assets. 


\section{Spearman Correlations}

Table 3 presents the Spearman correlations. Several points are noteworthy. First, firm valuation is negatively associated with multiple directorships, indicating that busy boards are associated with lower firm performance. Second, firms with busy boards have lower profitability. Third, firms with more busy boards have higher standard deviation of stock returns, higher standard deviation of ROA and higher standard deviation of operating cash flows.

Table 3

Spearman correlations

\begin{tabular}{lcccccccc}
\hline & TOBINQ & ROA & STDRET & STDROA & STDOCF & AVGDIR & BUSYBOD & D_BUSY \\
\hline TOBINQ & 1 & & & & & & & \\
ROA & 0.27 & 1 & & & & & & \\
& $(<0.0 .1)$ & & & & & & & \\
STDRET & -0.13 & -0.04 & 1 & & & & & \\
& $(0.04)$ & $(0.11)$ & & & & & & \\
STDROA & -0.18 & -0.11 & 0.33 & 1 & & & & \\
& $(0.07)$ & $(0.09)$ & $(0.07)$ & & & & & \\
STDCFO & -0.08 & -0.22 & 0.18 & 0.22 & 1 & & & \\
& $(0.11)$ & $(0.25)$ & $(0.11)$ & $(0.27)$ & & & & \\
AVGDIR & -0.16 & -0.08 & 0.11 & 0.08 & 0.09 & 1 & & \\
& $(0.08)$ & $(0.09)$ & $(0.12)$ & $(0.19)$ & $(0.11)$ & & & \\
BUSYBOD & -0.37 & -0.19 & 0.13 & 0.15 & 0.22 & 0.27 & 1 & \\
& $(0.03)$ & $(0.07)$ & $(<0.01)$ & $(0.03)$ & $(0.03)$ & $(0.08)$ & & \\
D_BUSY & -0.42 & -0.23 & 0.22 & 0.13 & 0.17 & 0.33 & 0.42 & \\
& $(<0.01)$ & $(0.04)$ & $(0.04)$ & $(0.12)$ & $(0.04)$ & $(0.04)$ & $(0.02)$ & \\
\hline
\end{tabular}

Notes: This table presents the Spearman correlations between the variables. TOBINQ is the market value of equity plus book value of total liabilities divided by total assets. AVGDIR is the total number of external directorships held by outside directors divided by the number of outside directors. BUSYBOD is the number of outside directors who are busy divided by number of outside directors. We consider a director as busy if he holds three or more directorships. D_BUSY is a dummy variable that equals one if $50 \%$ or more of the outside directors are busy and zero otherwise (D_BUSY). We classify a director as busy if he holds three or more directorships. STDRET is the standard deviation of daily stock returns in the past year. STDROA is the standard deviation of ROA in the past five years. STDCFO is the standard deviation operating cash flow divided by total assets in the past five years. The parenthesis contains the $p$-values.

\section{Firm Performance and Busy Boards}

Table 4 presents the firm-fixed ef fects re gression re sults of market-to-book ratio (TOBINQ) on busy boards. In Model (1), the estimated coefficient on AVGDIR (average directorships per outside director) is negative and statistically significant. $\mathrm{T}$ he $\mathrm{r}$ esults $\mathrm{i}$ ndicate $\mathrm{t}$ hat fi $\mathrm{rm}$ va luation is ne gatively associated with the multiple external directorships held by outside directors. Thus, in our 
sample, the busyness hypothesis dominates the reputation hypothesis. In terms of economic significance, if the average directorships per outside director increase by one standard deviation, Tobin's Q decreases by $3.67 \%$ relative to the sample mean.

The estimated coefficient on the interaction term, AVGDIR*CYCLE, is negative and statistically significant. This result is consistent with our hypothesis that firms with more matured life cycle experience lower firm valuation from having more outside directors with multiple external board appointments. Our results are consistent with the finding in Field et al. (2013) that busy directors are overstretched in reducing agency problems in older and more established firms. In terms of economic significance, if the average directorships per outside director increase by one standard deviation, Tobin's Q for firms with external financing needs decreases by $6.43 \%$ relative to the sample mean.

In Model (2), we measure directors' busyness with the percentage of busy outside directors (BUSYBOD). Following Fich and Shivdasani (2006), we classify director as busy if he holds three or more directorships. The results indicate that firm valuation is negatively associated with the percentage of busy outside directors. In terms of economic significance, if the percentage of busy outside directors increases by one standard deviation, Tobin's Q decreases by $2.75 \%$ relative to the sample mean. Furthermore, the estimated coefficient on the interaction term, BUSYBOD*CYCLE, is negative and statistically significant. Thus, when a firm's life cycle approached its maturity stage, its valuation is negatively associated with the percentage of busy outside directors. As firms mature, agency costs increase and thus reduces the demand for advising whilst increasing the demand for monitoring (Field et al., 2013). Our result suggests that busy directors are overstretched in monitoring firms in their maturity stage. In terms of economic significance, if the percentage of busy outside directors increases by one standard deviation, Tobin's Q for firms in their matured life cycle decreases by $6.28 \%$ relative to the sample mean. In contrast, for a firm in its introduction stage and growth stage, its valuation is positively associated with the percentage of busy outside directors. This suggests that for firms in their introduction stage and growth stage, the advising benefits and social connections arising from busy directors outweigh the monitoring ability of busy directors. 
Table 4

Firm valuation and busy outside directors

\begin{tabular}{lccc}
\hline & 1 & 2 & 3 \\
\hline Intercept & $0.8145(2.92)^{* * *}$ & $0.7223(3.04)^{* * *}$ & $0.215(3.22)^{* * *}$ \\
AVGDIR & $-0.0241(-2.11)^{* * *}$ & & \\
AVGDR*CYCLE & $-0.0082(-2.06)^{* *}$ & & \\
BUSYBOD & & $-0.1273(-3.14)^{* * *}$ & \\
BUSYBOD*CYCLE & & $-0.0741(-2.52)^{* * *}$ & \\
D_BUSY & & & $-0.0472(-3.38)^{* * *}$ \\
D_BUSY*CYCLE & & & $-0.0354(-2.71)^{* * *}$ \\
BDSIZE & $-0.0425(-1.09)$ & $-0.1059(-1.12)$ & $-0.023(-1.12)$ \\
OUTDIR & $0.0773(1.89)^{* *}$ & $0.0682(2.06)^{* * *}$ & $0.0512(2.04)^{* *}$ \\
DUAL & $-0.0192(-1.28)$ & $-0.0056(-1.03)$ & $-0.0177(-1.19)$ \\
CYCLE & $-0.1732(-2.01)^{* * *}$ & $-0.1153(-2.04)^{* * *}$ & $-0.1732(-1.80)^{*}$ \\
INSTI & $0.1651(1.81)^{*}$ & $0.1394(2.05)^{* *}$ & $0.2745(2.39)^{* * *}$ \\
LNAASSET & $0.5135(3.07)^{* * *}$ & $0.6172(3.25)^{* * *}$ & $0.5908(4.11)^{* * *}$ \\
SALECHG & $0.0736(1.05)$ & $0.114(1.25)$ & $0.129(1.31)$ \\
DEBT & $-0.1296(-1.54)$ & $-0.1573(-1.81)^{*}$ & $-0.0281(-0.65)$ \\
Adjusted $R^{2}$ & $27.15 \%$ & $29.43 \%$ & $31.08 \%$ \\
\hline
\end{tabular}

Notes: This table presents the firm-fixed effects regression results of firm valuation. The sample consists of 400 firms for 1,730 firm-year observations in Malaysia, Philippines, Singapore and Thailand during the period 2012 to 2016. The dependent variable is market value of equity plus book value of total liabilities divided by total assets (TOBINQ). AVGDIR is the total number of external directorships held by outside directors divided by the number of outside directors. BUSYBOD is the number of outside directors who are busy divided by number of outside directors. We consider a director as busy if he holds three or more directorships. D_BUSY is a dummy variable that equals one if $50 \%$ or more of the outside directors are busy and zero otherwise (D_BUSY). We classify a director as busy if he holds three or more directorships. BDSIZE is the number of directors on the board. OUTDIR is the proportion of outside directors on the board. Outside directors are directors who directors who are not classified as inside or grey directors, where grey directors include former employees or persons who have related party transactions with the firm. DUAL is a dummy variable that equals one if the CEO is chairman of the board and zero otherwise. CYCLE is an index that ranges from 1 to 5 according to the five firm life cycle stages (Dickinson 2011): introduction, growth, mature, shake-out and decline, based on expected cash flow generated separately from operating, investing and financing. INSTI is the proportion of common equity held by institutional shareholders. LNASSET is the natural logarithm of book value of total assets. ROA is net income divided by total assets. SALECHG is the prior year sales growth. DEBT is the long-term debt divided by book value of total assets. All models include firm fixed effects and dummy variables for country effects, industry effects and years effects (not tabulated). The parentheses contain the $t$-statistics on an adjusted basis using robust standard errors corrected for double (firm and year) clustering (Petersen, 2009). ***, **, and * denote statistical significance at the $1 \%, 5 \%$, and $10 \%$ levels, respectively.

In Model (3), we measure directors' busyness with a dummy variable (D_BUSY) that equals one if more than $50 \%$ of outside directors are busy, and zero otherwise. Our inferences are qualitatively similar. We continue to find that when the majority of outside directors is busy, firm v aluation is lower. 
Furthermore, we document that directors with multiple board appointments are effective in increasing value in firms in their introduction stage and growth stage. The advising skills and networks of busy directors are more valuable to firms in their growth life cycle which typically lack industry knowledge and market experience.

Another measure of firm performance is operating profitability. Table 5 presents the regression results of ROA on busy boards. Across all three proxies for multiple directorships, our results indicate that busy boards are negatively associated with firm profitability. Thus, holding multiple directorships reduces the monitoring effectiveness of outside directors. In terms of economic significance, in Column (2), if the percentage of busy outside directors increases by one standard deviation, the ROA decreases by $3.06 \%$ relative to the sample mean.

We also examine how the firm's life cycle affect the negative association between operating profitability and busy boards. The interaction between various proxies for busy boards and the firm's life cycle is negative and significant. Hence, the adverse effect of busy boards on operating profitability is more pronounced in firms in the maturity stage of their life cycle. The advising and networking benefits associated with directors who hold multiple board appointments is less useful for matured firms. In terms of economic significance, in Column (2), if the percentage of busy outside directors increases by one standard deviation, the profitability for firms in matured life cycle decreases by $5.15 \%$ relative to the sample mean.

Table 5

Operating profitability and busy outside directors

\begin{tabular}{lccc}
\hline & 1 & 2 & 3 \\
\hline Intercept & $0.0841(2.02)^{* *}$ & $0.0753(2.69)^{* * *}$ & $0.1367(3.02)^{* * *}$ \\
AVGDIR & $-0.0008(-2.05)^{* *}$ & & \\
AVGDR*CYCLE & $-0.0002(-1.98)^{* *}$ & & \\
BUSYBOD & & $-0.0042(-2.33)^{* * *}$ & \\
BUSYBOD*CYCLE & & $-0.0013(-2.05)^{* *}$ & \\
D_BUSY & & $-0.0023(-2.51)^{* * *}$ \\
D_BUSY*CYCLE & & & $-0.0874(-2.29)^{* * *}$ \\
CYCLE & $0.0053(-0.73)$ & $0.0712(-1.17)$ & $-0.0056(-1.05)$ \\
BDSIZE & $-0.0323(-1.09)$ & $-0.1059(-1.12)$ & $-0.023(-1.12)$ \\
\hline & & & $($ continued on next page $)$
\end{tabular}


Table 5: (continued)

\begin{tabular}{lccc}
\hline & 1 & 2 & 3 \\
\hline OUTDIR & $0.226(1.43)$ & $0.1925(1.60)$ & $0.1037(1.62)$ \\
LNAASSET & $0.2731(2.51)^{* * *}$ & $0.3015(2.46)^{* * *}$ & $0.229(2.38)^{* * *}$ \\
SALECHG & $0.0563(1.29)$ & $0.0217(1.10)$ & $0.0074(0.65)$ \\
DEBT & $-0.1664(-0.55)$ & $-0.0211(-0.53)$ & $-0.0429(-1.07)$ \\
Firm fixed effects & Yes & Yes & Yes \\
Country indicators & Yes & Yes & Yes \\
Year indicators & Yes & Yes & Yes \\
Adjusted $R^{2}$ & $9.32 \%$ & $11.82 \%$ & $12.15 \%$ \\
\hline
\end{tabular}

Notes: This table presents the firm-fixed effects regression results of operating profitability. The dependent variable is return on assets (ROA). AVGDIR is the total number of external directorships held by outside directors divided by the number of outside directors. BUSYBOD is the number of outside directors who are busy divided by number of outside directors. We consider a director as busy if he holds three or more directorships. D_BUSY is a dummy variable that equals one if $50 \%$ or more of the outside directors are busy and zero otherwise (D_BUSY). We classify a director as busy if he holds three or more directorships. BDSIZE is the number of directors on the board. OUTDIR is the proportion of outside directors on the board. Outside directors are directors who directors who are not classified as inside or grey directors, where grey directors include former employees or persons who have related party transactions with the firm. DUAL is a dummy variable that equals one if the CEO is chairman of the board and zero otherwise. CYCLE is an index that ranges from 1 to 5 according to the five firm life cycle stages (Dickinson, 2011): introduction, growth, mature, shake-out and decline, based on expected cash flow generated separately from operating, investing and financing. INSTI is the proportion of common equity held by institutional shareholders. LNASSET is the natural logarithm of book value of total assets. ROA is net income divided by total assets. SALECHG is the prior year sales growth. DEBT is the long-term debt divided by book value of total assets. All models include firm fixed effects and dummy variables for country effects, industry effects and years effects (not tabulated). The parentheses contain the $t$-statistics on an adjusted basis using robust standard errors corrected for double (firm and year) clustering (Petersen, 2009). ***,**, and * denote statistical significance at the $1 \%, 5 \%$, and $10 \%$ levels, respectively.

\section{Operating Risk and Busy Boards}

This section examines the association between busy boards and operating risk. Our proxies for operating risk are: (i) standard deviation of stock returns in the past five years, (ii) standard deviation of return on assets in the past five years, and (iii) standard deviation of cash flow from operations in the past five years.

Table 6 presents the regression results of operating risk on the percentage of busy outside directors (BUSYBOD). In Model (1), the coefficient BUSYBOD is positive and significant at the $1 \%$ level, indicating that firms with higher percentage of busy directors have higher standard deviation of stock returns in the past five years. In Model (2), we find firms with higher percentage of busy directors have volatility of operating profitability proxied by the standard deviation of return on assets in the past five years. Similarly, in Model (3), we document that firms with higher percentage of busy directors have higher 
operating cash flow volatility proxied by the standard deviation of cash flow from operations in the past five years. Collectively, these results suggest that firms with higher percentage of busy directors are associated with higher operating risk. More generally, these results support the busyness hypothesis, which posits that busy directors are over-stretched in monitoring the risk-taking activities of the managers. In addition, the interaction between BUSYBOD and CYCLE is positive and statistically significant. Thus, the positive association between operating risk and percentage of busy directors is higher in firms in the maturity stage of their life cycle. ${ }^{8}$

Table 6

Regression of firm's operating risk on busy boards

\begin{tabular}{lccc}
\hline & 1 & 2 & 3 \\
\hline Dependent variable & STDRET & STDROA & STDOCF \\
\hline Intercept & $0.7435(3.87)^{* * *}$ & $0.2164(2.98)^{* * *}$ & $1.0072(3.55)^{* * *}$ \\
BUSYBOD & $0.0281(2.52)^{* * *}$ & $0.4956(2.36)^{* * *}$ & $0.0743(2.02)^{* *}$ \\
BUSYBOD*CYCLE & $0.0053(2.04)^{* *}$ & $0.0091(2.11)^{* *}$ & $0.0091(1.83)^{*}$ \\
CYCLE & $0.1563(1.19)$ & $0.3255(1.28)$ & $0.11834(1.57)$ \\
BDSIZE & $0.0573(1.17)$ & $0.1347(0.42)$ & $0.9382(1.31)$ \\
OUTDIR & $-0.827(-1.79)^{*}$ & $-0.601(-1.81)^{*}$ & $-0.2385(-2.04)^{* * *}$ \\
DUAL & $0.0652(1.03)$ & $0.1349(1.29)$ & $0.2375(1.46)$ \\
LNASSET & $-0.827(-3.55)^{* * * *}$ & $-0.601(-2.88)^{* * *}$ & $-0.295(-3.02)^{* * *}$ \\
SALECHG & $0.0816(2.52)^{* * *}$ & $0.2193(2.67)^{* * *}$ & $0.1884(2.029)^{* * *}$ \\
LTDEBT & $0.5926(2.37)^{* * *}$ & $0.7235(1.80)^{* *}$ & $0.3851(2.29)^{* * *}$ \\
Country controls & Yes & Yes & Yes \\
Year controls & Yes & Yes & Yes \\
Industry controls & Yes & Yes & Yes \\
Adjusted $R^{2}$ & $5.8 \%$ & $6.3 \%$ & $4.1 \%$ \\
\hline
\end{tabular}

Notes: This table presents the estimation results of the regression of firm's operating risk on busy boards. In Column (1), the dependent variable is the standard deviation of daily stock returns in the past year (STDRET). In Column (2), the dependent variable is the standard deviation of return on assets in the past five years (STDROA). In Column (3), the dependent variable is the standard deviation operating cash flow divided by total assets in the past five years (STDOCF). AVGDIR is the total number of external directorships held by outside directors divided by the number of outside directors. BUSYBOD is the number of outside directors who are busy divided by number of outside directors. We consider a director as busy if he holds three or more directorships. D_BUSY is a dummy variable that equals one if $50 \%$ or more of the outside directors are busy and zero otherwise (D_BUSY). We classify a director as busy if he holds three or more directorships. BDSIZE is the number of directors on the board. OUTDIR is the proportion of outside directors on the board. Outside directors are directors who directors who are not classified as inside or grey directors, where grey directors include former employees or persons who have related party transactions with the firm. DUAL is a dummy variable that equals one if the CEO is chairman of the board and zero otherwise. CYCLE is an index that ranges from 1 to 5 according to the five firm life cycle 
stages (Dickinson, 2011): introduction, growth, mature, shake-out and decline, based on expected cash flow generated separately from operating, investing and financing. INSTI is the proportion of common equity held by institutional shareholders. LNASSET is the natural logarithm of book value of total assets. ROA is net income divided by total assets. SALECHG is the prior year sales growth. DEBT is the long-term debt divided by book value of total assets. All models include firm fixed effects and dummy variables for country effects, industry effects and years effects (not tabulated). The parentheses contain the $t$-statistics on an adjusted basis using robust standard errors corrected for double (firm and year) clustering (Petersen, 2009). ***, **, and * denote statistical significance at the $1 \%, 5 \%$, and $10 \%$ levels, respectively.

\section{Endogeneity}

We use two-stage least-squares regressions to mitigate endogeneity concerns. In the first stage, we model board busyness. Following Field et al. (2013), our instrumental variables include: (i) a dummy variable for the presence of a busy board at the start of the sample period, and (ii) the number of independent directors over 60 years of age. We expect that firms with busy boards at the start of the sample period are more likely to have busy boards in subsequent years. We expect that older directors are more likely to serve on multiple boards because they are more likely to be retired and thus have fewer time constraints. In the second stage, we regress firm performance (TOBINQ and ROA) on the predicted board busyness estimated in the first stage.

Table 7 presents the results of the two-stage least-squares regressions. In Column (1), the percentage of busy directors on the board is positively associated with the presence of a busy board at the start of the sample period and the number of independent directors over 60 years of age. Thus, both instruments are positive and significantly related to board busyness.

In Column (2), we regress firm performance (TOBINQ) on the predicted board busyness estimated in the first stage. After controlling for endogeneity, we continue to find that firm valuation is negatively associated with busy boards. Furthermore, we find that the negative association between firm valuation and busy boards is more pronounced for firms in the maturity stage in their lifecycle. In Column (3), we regress operating profitability (ROA) on the predicted board busyness estimated in the first stage. After controlling for endogeneity, we find that operating profitability is negatively associated with busy boards. Furthermore, in firms with busy those in the maturity stage in their lifecycle with higher percentage of have lower operating profitability. 
Table 7

Two stage least squares regressions: Busy boards and firm performance

\begin{tabular}{lccc}
\hline & First stage & Second stage & Second stage \\
\hline Dependent variable & 1 & 2 & 3 \\
INITIALBUSY & BUSYBOD & TOBINQ & ROA \\
DIRABOVE60 & $0.4132(2.57)^{* * *}$ & & \\
Predicted BUSYBOD & $0.1571(2.01)^{* *}$ & & \\
Predicted & & $-0.0037(-2.49)^{* * *}$ & $-0.1128(-2.19)^{* * *}$ \\
BUSYBOD*CYCLE & & $-0.0021(-2.09)^{* *}$ & $-0.0954(-1.83)^{*}$ \\
\hline
\end{tabular}

Notes: The first-stage regression models board busyness (BUSYBOD), which is the number of busy outside directors divided by total outside directors. The first stage regression includes two instrumental variables: (i) a dummy variable equal to one for firms with a busy board at the start of the sample period (INITIALBUSY), and (ii) the number of independent directors over 60 years of age (DIRABOVE60). The dependent variables in the second-stage regressions are the market-to-book equity (TOBINQ) and return on assets (ROA). Predicted BUSYBOD is the predicted board busyness from the first stage regression. For parsimony, the control variables are not tabulated in the second stage. All models include dummy variables for country effects, industry effects and years effects (not tabulated). The parentheses contain the $t$-statistics on an adjusted basis using robust standard errors corrected for double (firm and year) clustering (Petersen, 2009). ***, **, and * denote statistical significance at the $1 \%, 5 \%$, and $10 \%$ levels, respectively.

\section{CONCLUSION}

Under the reputation hypothesis, directors who hold multiple external board seats are effective monitors of management. Thus, firm performance is positively associated with busy boards. In contrast, under the busyness hypothesis, multiple directorships increase the workload for directors. Thus, busy directors are overstretched and they may not have sufficient time and energy to monitor and to advise the firm's management.

Using a sample of listed firms in Malaysia, Philippines, Singapore and Thailand, we examine the association between busy board of directors and firm performance. First, we find that firm performance (measured by operating profitability a nd $\mathrm{m}$ arket-to-book e quity) i s n egatively a ssociated w ith busy boards. Thus, in our sample, on average, the results suggest that the busyness hypothesis dominates the reputation hypothesis. Second, we document a positive association between busy boards and operating risk. Specifically, we provide evidence on a channel in which busy directors affect firm performance by demonstrating that firms with higher percentage of busy directors have higher stock return volatility and higher operating return volatility. Third, we find that the association between firm performance and busy boards is conditional on the 
firm's life cycle stage. For firms in the growth stage, busy boards are beneficial to firm performance suggesting that the experience knowledge and reputation accumulated with multiple directorships help busy directors to more effectively advise these firms. In contrast, for firms in the maturity stage of their life cycle, busy boards are detrimental to firm performance suggesting the monitoring role of board is weakened by multiple directorships.

\section{NOTES}

1. Announcements of inside director appointments (departures from) to external boards elicit positive (negative) stock market reactions. Thus, outside directorships provide reputation incentives that strengthen inside directors' performance on their own boards and increase their independence from the CEO.

2. The number of external board seats held by a director is positively associated with firm performance, firm size, education (having a law degree and MBA) but negatively associated with female directors.

3. They find that stock returns around outside directorships appointment are higher when executives accept an outside directorship in a financial, high-growth, or related-industry firm.

4. Firms with the smallest decrease in board connections experience the greatest improvement in operating performance and advising while firms with the greatest decrease in board connections experience null or negative effects on operating performance and advising.

5. They find that the labour market penalises directors who approve bad acquisitions but does not reward them for good mergers.

6. The authors conclude that reputation hypothesis (resource dependency theory) effect dominates the over-boarding hypothesis (agency theory) effect at a lower level of busyness. As busyness increases beyond a certain level, the over-boarding effect dominates the reputation effect.

7. Dickinson (2011) points out that "both size and firm age are common proxies for life cycle. When size and age are used as a life cycle proxy, an implicit assumption is that a firm moves monotonically through its life cycle. This assumption arises because product life cycles are characterised by forward progression from introduction to decline. However, a firm is a portfolio of multiple products, each at potentially a different product life cycle stage. Substantial product innovations, expansion into new markets or structural change can cause firms to move across life cycle stages non-sequentially."

8. Our results are qualitatively similar using the other proxies for busy boards (AVGDIR and D_BUSY). 


\section{REFERENCES}

Ahn S., Jiraporn, P., \& Kim, Y. S. (2010). Multiple directorship and acquirer returns. Journal of Banking and Finance, 34(9), 2011-2026. https://doi.org/10.1016/j. jbankfin.2010.01.009

Anthony, J., \& Ramesh, K. (1992). Association between accounting performance measures and stock prices. Journal of Accounting and Economics, 15, 203-227. https://doi. org/10.1016/0165-4101(92)90018-W

Black, E. L. (1998). Life-cycle impacts on the incremental value-relevance of earnings and cash flow measures. Journal of Financial Statement Analysis, 4, 40-56.

Booth, J. R., \& Deli, D. N. (1996). Factors affecting the number of outside directorships held by CEOs. Journal of Financial Economics, 40(1), 81-104. https://doi. org/10.1016/0304-405X(95)00838-6

Brickley, A. J., Linck, S. J., \& Coles, L. J. (1999). What happens to CEOs after they retire? New evidence on career concerns, horizon problems, and CEO incentives. Journal of Financial Economics, 52(3), 341-377. https://doi.org/10.1016/S0304405X(99)00012-4

Brown, A., Dai, J., \& Zur, E. (2019). Too busy or well-connected? Evidence from a shock to multiple directorships. The Accounting Review, 94(2), 83-104.

Carney, R. W., \& Child, T. B. (2013). Changes to the ownership and control of East Asian corporations between 1996 and 2008: The primacy of politics. Journal of Financial Economics, 107(2), 494-513.

Cashman, G. D., Gillan, S. L., \& Jun, C. (2012). Going overboard? On busy directors and firm value. Journal of Banking \& Finance, 36(12), 3248-3259. https://doi. org/10.1016/j.jbankfin.2012.07.003

Chiu, P. C., Teoh, S. H., \& Tian, F. (2013). Board interlocks and earnings management contagion. The Accounting Review, 88(3), 915-944. https://doi.org/10.2308/accr50369

Cohen, L., Frazzini, A., \& Malloy, C. (2008). The small world of investing: Board connections and mutual fund returns. Journal of Political Economy, 116(5), 951979. https://doi.org/10.1086/592415

Cooper, E., \& Uzun, H. (2012). Directors with a full plate: The impact of busy directors on bank risk. Managerial Finance, 38(6), 571-586. https://doi. org/10.1108/03074351211226238

Dickinson, V. (2011). Cash flow patterns as a proxy for firm life cycle. The Accounting Review, 86(6), 1969-1994. https://doi.org/10.2308/accr-10130

Di Pietra, R., Grambovas, C. A., Raonic, I., \& Riccaboni, A. (2008). The effects of board size and 'busy' directors on the market value of Italian companies. Journal of Management and Governance, 12, 73-91. https://doi.org/10.1007/s10997-0089044-y

Elyasiani, E., \& Zhang, L. (2015). Bank holding company performance, risk, and busy board of directors. Journal of Banking \& Finance, 60, 239-251. https://doi. org/10.1016/j.jbankfin.2015.08.022 
Falato, A., Kadyrzhanova, D., \& Lel, U. (2014). Distracted directors: Does board business hurt shareholder value? Journal of Financial Economics, 113(3): 404-426. https://doi.org/10.1016/j.jfineco.2014.05.005

Faleye, O., Hoitash, R., \& Hoitash, U. (2011). The costs of intense board monitoring. Journal of Financial Economics, 101(1), 160-181. https://doi.org/10.1016/j. jifineco.2011.02.010

Faleye, O., Kovacs, T., \& Venkateswaran, A. (2014). Do better-connected CEOs innovate more? Journal of Financial and Quantitative Analysis, 49(5/6), 1201-1225. https://doi.org/10.1017/S0022109014000714

Fama, E. F, \& Jensen, M. C. (1983). Separation of ownership and control. The Journal of Law and Economics, 26(2), 301-325. https://doi.org/10.1086/467037

Ferris, S. P., \& Liao, M. Y. (2019). Busy boards and corporate earnings management: An international analysis. Review of Accounting and Finance, 18(4), 533-556. https://doi.org/10.1108/RAF-07-2017-0144

Ferris, S. P., Jagannathan, M., \& Pritchard, A. C. (2003). Too busy to mind the business? Monitoring by directors with multiple board appointments. Journal of Finance, 58(3), 1087-1111. https://doi.org/10.1111/1540-6261.00559

Ferris, S. P., Jayaraman, N., \& Liao, M. Y. (2019). Labor market consequences for busy directors: Evidence from international mergers and acquisitions. The Journal of Financial Research, 52(3), 449-489. https://doi.org/10.1111/jfir.12180

Ferris, S. P., Jayaraman, N., \& Liao, M. Y. (2020). Better directors or distracted directors? An international analysis of busy boards. Global Finance Journal. Forthcoming. https://doi.org/10.1016/j.gfj.2018.05.006

Fich, E. M., \& Shivdasani, A. (2006). Are busy boards effective monitors? Journal of Finance, 61(2), 689-724. https://doi.org/10.1111/j.1540-6261.2006.00852.x

Field, L., Lowry, M., \& Mkrtchyan, A. (2013). Are busy boards detrimental? Journal of Financial Economics, 109(1), 63-82. https://doi.org/10.1016/j. jineco.2013.02.004

Fracassi, C. (2017). Corporate finance policies and social networks. Management Science, 63(8), 2420-2438. https://doi.org/10.1287/mnsc.2016.2433

Gilson, S. C. (1990). Bankruptcy, boards, banks, and blockholders: Evidence on changes in corporate ownership and control when firms default. Journal of Financial Economics, 27(2), 355-387. https://doi.org/10.1016/0304-405X(90)90060-D

Gort, M., \& Klepper, S. (1982). Time paths in the diffusion of product innovations. The Economic Journal, 92(367), 630-653.

Hauser, R. (2018). Busy directors and firm performance: Evidence from mergers. Journal of Financial Economics, 128(1), 16-37. https://doi.org/10.1016/j. jifineco.2018.01.009

Jensen, M. C., \& Ruback, R. S. (1983). The market for corporate control. Journal of Financial Economics, 11(1-4), 5-50. https://doi.org/10.1016/0304405X(83)90004-1

Jiraporn, P., Davidson, W. N., DaDalt, P., \& Ning, Y. (2009). Too busy to show up? An analysis of directors' absences. The Quarterly Review of Economics and Finance, 49(3), 1159-1171. https://doi.org/10.1016/j.qref.2008.08.003 
Kaplan, S. N., \& Reishus, D. (1990). Outside directorships and corporate performance. Journal of Financial Economics, 27(2), 389-410. https://doi.org/10.1016/0304405X(90)90061-4

Kutubi, S., Ahmed, K., \& Khan, H. (2018). Bank performance and risk-taking: Does directors' busyness matter? Pacific-Basin Finance Journal, 50, 184-199. https:// doi.org/10.1016/j.pacfin.2017.02.002

Lee, K. W., \& Lee, C. F. (2014). Are multiple directorships beneficial in East Asia? Accounting and Finance, 54, 999-1032. https://doi.org/10.1111/acfi.12008

Lins, K. (2003). Equity ownership and firm value in emerging markets. Journal of Financial and Quantitative Analysis, 38, 159-184. https://doi.org/10.2307/4126768

Masulis, R. W., \& Mobbs, S. (2011). Are all inside directors the same? Evidence from the external directorship market. Journal of Finance, 66(3), 823-872. https://doi. org/10.1111/j.1540-6261.2011.01653.x

Monetary Authority of Singapore. (2018). Code of Corporate Governance 2018. Retrieved from https://www.mas.gov.sg/-/media/MAS/Regulations-and-Financial-Stability/ Regulatory-and-Supervisory-Framework/Corporate-Governance-of-ListedCompanies/Code-of-Corporate-Governance-6-Aug-2018.pdf

Perry, T., \& Peyer, U. (2005). Board seat accumulation by executives: A shareholder's perspective. Journal of Finance, 60, 2083-2123. https://doi.org/10.1111/j.15406261.2005.00788.x

Pombo, C., \& Gutiérrez, L. H. (2011). Outside directors, board interlocks and firm performance: Empirical evidence from Colombian business groups. Journal of Economics and Business, 63(4), 251-277. https://doi.org/10.1016/j. jeconbus.2011.01.002

Sarkar, J., \& Sarkar, S. (2009). Multiple board appointments and firm performance in emerging economies: Evidence from India. Pacific-Basin Finance Journal, 17(2), 271-293. https://doi.org/10.1016/j.pacfin.2008.02.002

Securities Commission Malaysia. (2012). Malaysia Code on Corporate Governance. Retreived from http://micg.org.my/upload/file/articles/11/CODE-CG-2012.pdf

Shivdasani, A. (1993). Board composition, ownership structure and hostile takeovers. Journal of Accounting and Economics, 16, 167-198. https://doi. org/10.1016/0165-4101(93)90009-5

Smith, C., \& Watts, R. (1992). The investment opportunity set and corporate financing, dividend and compensation policies, Journal of Financial Economics, 40, $263-$ 292. https://doi.org/10.1016/0304-405X(92)90029-W

Yermack, D. (1996). Higher market valuation of companies with a small board of directors. Journal of Financial Economics, 40, 185-211. https://doi.org/10.1016/0304405X(95)00844-5 